\title{
References:
}

1. Bezrodnikh T.V. (2016) Interactive technologies at universities - the technologies of building student's social and pedagogical competences. Problems of modern pedagogical education. № 52-5. P. 58-65. (in Russian)

2. Kicherova M.N., Efimova G.Z. (2016) Educational quests as a creative educational technology for students of the new generation. Internet-magazine "World of science», volume 4, number $5 \mathrm{P}$. 1-10 http://mir-nauki.com/PDF/28PDMN516.pdf (in Russian)

3. Malinovskaya M.P. (2017) Educational quest in student's professional competences building in pedagogical university. International scientific magazine» Symbol of science». № 04-2. P. 164-170 (in Russian)

4. Mezientzeva M.E.(2017) Quest as a modern method of active methods of teaching foreign languages. Questions of methodology ofteaching at universities. V. 6. №21. P. 75-83. DOI: 10/18720/HUM/ISSN 22278591.21.8 (in Russian)

5. Sokol I.M. (2014) Classification quests. Young scientist № 6 (09) June. P. 138-140 http://molodyvcheny.in.ua/files/journal/2014/6/89.pdf. (in Russian)

DOI https://doi.org/10.30525/978-9934-588-80-8-2.37

\section{INTEGRATING ESSENTIAL SOFT SKILLS IN TEACHING ENGLISH TO LAW STUDENTS}

\author{
Zhyhadlo O. Yu. \\ Candidate of Philological Sciences, \\ Lecturer at the Foreign Languages Department, Law School \\ Taras Shevchenko National University of Kyiv \\ Kyiv, Ukraine
}

Teaching has always been a challenging task requiring maximum effort and involvement on behalf of the instructor. However, teaching in the $21^{\text {st }}$ century is even more challenging since the teacher is expected to focus not only on giving knowledge of the subject, but also on a scope of other issues a contemporary society faces. Due to rapid technology advances, quick and easy access to information, changes in the labour market, students have to cope with new challenges and face many non-academic requirements in order to meet volatile employment standards which are often at variance with what they have been taught at school and university. It appears thus to be the teacher's task to boost students' adaptability, communication skills, 
problem solving and other people skills for the latter to be more effective in their workplace. Lessons of foreign languages and particularly foreign languages for specific purposes may be an invaluable tool to bolster a variety of soft skills of future professionals. So the aim of the study is to highlight those of soft skills which may be crucial for future lawyers and to suggest some techniques to enhance them during English lessons.

Soft skills or employability or transferable skills may be defined as general skills which are vital «for success in the labour market at all employment levels and in all sectors» [5]. Soft skills are often opposed to hard skills which are «learned abilities acquired and enhanced through practice, repetition and education» [4]. Though hard skills generally foster the productivity of an employee, they do not constitute the sole prerequisite of the employee's efficiency and success. Typically, employees are expected to demonstrate other skills in addition to their knowledge, aptitude and work experience to meet the expectations of a contemporary employer. So soft skills do not depend on knowledge or expertise, but they are rather a complex phenomenon which includes interpersonal and management skills which improve one's employability and career prospects.

The importance of soft skills and the necessity to integrate them into university curricula have been the subject of research of Ukrainian (O. Abashkina, I. Ivanova, K. Koval) and foreign scholars (O. Hajjaj, I. Mandysova, D. Price, M. Robles, E. Spirovska Tevdovska). There is no universal classification of soft skills, as researchers offer various lists of the skills they define as «soft» or group them in different ways. However, soft skills are defined as a «combination of interpersonal skills and personal or career attributes» [6, p. 457] or a collection of «personal, communication and management skills» [1, p. 165].

Basing on the abovementioned taxonomy, we would like to delineate some of the most important soft skills for future legal professionals and to demonstrate how these soft skills may be integrated in the process of learning and teaching English for specific legal purposes.

Problem solving, negotiating and managing conflicts (mediation), which refer to the group of personal soft skills, seem to be essential for law students. At the lessons of Legal English students may be exposed to various disputable questions in different areas of law or some ethical or moral dilemmas. They can have group discussions in the target language, discuss pros and cons of solutions, and eventually vote for the best one. Alternatively, students can deal with case studies, which are real-life situations in a mock professional setting, which will not only allow them to practise legal terminology, but will also trigger necessary people skills and train critical thinking. 
The group of communication or people-related skills contains dealing with different communication styles, speaking clearly and concisely, asking right questions, rephrasing to make sure the interlocutor understands you, demonstrating positive attitude and friendliness. These skills are absolutely vital for lawyers, as they may need to communicate with clients and other legal professionals in the course of their work. As far as clients' expectations are concerned, the former would like their lawyer «to communicate well, to show dignity and respect, to provide information, to listen and to involve them in decision-making» [3, p. 90]. Thus building rapport, representing themselves in a favourable light, speaking and writing persuasively and an ability to explain complicated issues in simple terms to lay people are the skills that should be brought into the context of lessons of Legal English. This can be achieved with the help of role-play exercises, when students are asked to simulate various communicative situations from a professional context. One of the effective situation-based tasks is a mock lawyer-client interview. It allows students to demonstrate the whole range of interpersonal and communication skills which include establishing rapport, active listening, asking the right questions to encourage the client to tell their story in more detail and speaking clearly.

Being able to communicate effectively both orally and in writing are among the key skills of a flourishing lawyer and are the soft skills most commonly required by employers. Developing students' speaking and writing skills is inherent in the program of ESP courses and there are many tasks allowing students to communicate orally in pairs or groups. According to E. Spirovska Tevdovska [7, p. 103], group work involving discussions and debates as well as delivering PowerPoint presentations are essential for developing students' speaking skills in order to be able to «communicate their message and/or opinion effectively».

At the lessons of Legal English students are given an opportunity to enhance and consolidate their writing skills by means of producing a variety of texts including business correspondence, e.g. e-mails, application and prospecting letters; legal writing, e.g. a letter of advice to a client, legal memoranda, contract drafting. To make the performance of writing tasks even more effective, peer review may be encouraged.

Another group of soft skills is management skills which are related to professionalism or work ethic. It comprises such important skills as teamwork, responsibility, commitment, time management and integrity. It may seem that this collection of soft skills is relevant for any profession; however, for lawyers they are essential. According to Model Rules of Professional Conduct set by the American Bar Association [2], «in all professional functions a lawyer should be competent, prompt and diligent». By means of starting every lesson with a clear agenda of what is planned for 144 
the lesson and finishing it with the overview of what has been done at the lesson and what has been achieved by the students, setting strict deadlines for task performance, including self-assessment tasks in the coursework, the teacher will foster the development of students' time management skills, boost their commitment and responsibility. Encouraging students to cooperate in small or large groups to work on a project, to prepare for debates or to play a game will certainly teach them to work together, listen to and help each other to achieve a common goal.

In conclusion, soft skills proved to be as important for graduates' employability and career growth as their knowledge and expertise. Some soft skills may be essential for certain professions, thus universities should integrate training of the selected soft skills in their curricula. Lessons of Legal English offer a variety of possibilities of bringing them into the classroom and introducing some techniques for training essential soft skills to future members of the legal profession. These methods and techniques proved to be effective and appealing to students.

\section{References:}

1. Коваль К. О. Розвиток «Soft Skills» у студентів - один 3 важливих чинників працевлаштування. Вісник Вінницького політехнічного інституту. 2015. № 2. С. 162-167.

2. American Bar Association. Model Rules of Professional Conduct: Preamble and Scope. URL: https://www.americanbar.org/groups/ professional_responsibility/publications/model_rules_of_professional_condu ct/ (дата звернення 23.09.2020).

3. Elbers N. A., Akkermans A.J., van Wees K. A. P. C., Cuijpers P., Bruinvels D. J. Exploring Lawyer-Client Interaction. Psychological Injury and Law. 2012. P. 89-94. DOI: 10.1007/s12207-012-9120-0.

4. Investopedia. Hard Skills. URL: https://www.investopedia.com/ terms/h/hard-skills.asp (дата звернення 23.09.2020).

5. Price D. Five Easy Ways to Integrate Soft Skills in your Class. URL: https://www.cambridge.org/elt/blog/2015/10/22/5-easy-ways-to-integratesoft-skills-in-your-class/ (дата звернення 23.09.2020).

6. Robles M. M. Executive Perceptions of the Top 10 Soft Skills Needed in Today's Workplace. Business Communication Quarterly. 2012. № 75 (4). P. 453-465. DOI: 10.1177/1080569912460400.

7. Spirovska Tevdovska E. Integrating Soft Skills in Higher Education and the EFL Classroom: Knowledge Beyond Language Learning. SEEU Review. Special Edition. 2015. Volume 11. Issue 2. P. 95-106. DOI: 10.1515/seeur-2015-0031. 